\title{
Biological nitrogen fixation in soybean under water restriction and exposed to 1-methylcyclopropene
}

\author{
Vitor Camargo do Nascimento Junior ${ }^{(1)}$, Cássio Egidio Cavenaghi Prete ${ }^{(1)}$ and Marco Antonio Nogueira(2)
}

\begin{abstract}
(1)Universidade Estadual de Londrina, Centro de Ciências Agrárias, Departamento de Agronomia, Rodovia Celso Garcia Cid, PR 445, Km 380, Campus Universitário, Caixa Postal 10011, CEP 86055-900 Londrina, PR, Brazil. E-mail: vcnjr@sercomtel.com.br, cassio@uel.br (2)Embrapa Soja, Rodovia Carlos João Strass, s/no, Acesso Orlando Amaral, Distrito de Warta, Caixa Postal 231, CEP 86001-970 Londrina, PR, Brazil. E-mail: marco.nogueira@embrapa.br
\end{abstract}

\begin{abstract}
The objective of this work was to assess the effects of 1-methylcyclopropene (1-MCP) on traits related with biological nitrogen fixation on 'BRS 268' soybean (Glycine max) subjected to water restriction. Plants were either exposed to drought between $32\left(R_{2}\right)$ and $47\left(R_{3}\right)$ days after sowing $(D A S)$ or kept well-watered, in combination with exposure or not to 1-MCP. On the second day under drought (34 DAS), plants from both water conditions were exposed to 1-MCP in a hermetically sealed chamber for 15 hours. Control plants, dry or well-watered, that were not exposed to 1-MCP were kept in a separate chamber. At $36\left(\mathrm{R}_{2}\right)$ and $47\left(\mathrm{R}_{3}\right)$ DAS, shoot and root dry weights, leaf area index, number and dry weight of nodules, total ureides in sap, and $\mathrm{N}$ concentration in leaves were assessed. From 47 DAS on, extra plants were well watered until physiological maturity $\left(\mathrm{R}_{8}\right)$ and assessed for yield components. Water restriction increased ureides in sap and reduced $\mathrm{N}$ in leaves in $\mathrm{R}_{2}$; reduced the number and mass of nodules, shoot dry weight, and leaf area index in $\mathrm{R}_{3}$; and reduced the number of pods and seed mass of plants not exposed to 1-MCP. However, when plants are exposed to $1-\mathrm{MCP}$, there is an attenuation of water restriction effects.
\end{abstract}

Index terms: Bradyrhizobium, Glycine max, inhibitor of ethylene, nodulation, water stress.

\section{Fixação biológica do nitrogênio em soja sob restrição hídrica e exposta ao 1-metilciclopropeno}

\begin{abstract}
Resumo - O objetivo deste trabalho foi avaliar os efeitos do 1-metilciclopropeno (1-MCP) em parâmetros relacionados à fixação biológica de nitrogênio em soja (Glycine max) 'BRS 268' submetida à restrição hídrica. As plantas foram submetidas à seca entre $32\left(R_{2}\right)$ e $47\left(R_{3}\right)$ dias após a semeadura (DAS) ou mantidas bem irrigadas, em combinação com exposição ou não ao 1-MCP. No segundo dia sob seca (34 DAS), as plantas de ambas as condições hídricas foram expostas ao 1-MCP em câmara hermeticamente fechada por 15 horas. As plantas-controle, sob restrição hídrica ou bem irrigadas, não expostas ao 1-MCP foram mantidas em câmara separada. Aos $36\left(\mathrm{R}_{2}\right)$ e $47\left(\mathrm{R}_{3}\right)$ DAS, foram avaliados massa seca da parte aérea e das raízes, índice de área foliar, número e massa seca de nódulos, ureídos totais na seiva e concentração de $\mathrm{N}$ foliar. A partir dos $47 \mathrm{DAS}$, as plantas remanescentes foram mantidas bem irrigadas até a maturação fisiológica $\left(\mathrm{R}_{8}\right)$ e os componentes de produção foram avaliados. A restrição hídrica aumentou os ureídos na seiva e reduziu o $\mathrm{N}$ foliar em $\mathrm{R}_{2}$; reduziu o número e a massa de nódulos, a massa seca da parte aérea e o índice de área foliar em $\mathrm{R}_{3}$; e reduziu o número de vagens e a massa de sementes em plantas sem exposição ao 1-MCP. No entanto, quando as plantas são expostas ao 1-MCP, há atenuação do efeito da restrição hídrica.
\end{abstract}

Termos para indexação: Bradyrhizobium, Glycine max, inibidores de etileno, nodulação, estresse hídrico.

\section{Introduction}

Drought is one of the main concerns in cropping systems, especially at critical stages of the plant cycle, such as the reproductive ones (Nascimento et al., 2011), and may lead to severe losses. Several physiological processes are impaired in soybean (Glycine $\max \mathrm{L}$.) under drought, among which biological nitrogen fixation (BNF) is one of the most sensitive, even more than transpiration and photosynthesis (Sinclair et al., 2007; Cerezini et al., 2014).

Ethylene is known for acting in the ripening process, but it is also produced by plants under stressing conditions, including drought, which leads to a cascade of events that result in senescence. Compounds like 1-methylcyclopropene (1-MCP) compete with ethylene for binding sites in cell receptors and block the cascade of events associated to ripening and 
senescence (Li et al., 2016). Based on this information, the use of an inhibitor of ethylene might attenuate the effect of drought on plants.

$1-\mathrm{MCP}$ is widely used to keep the quality and prolong the shelf life of climacteric and non-climacteric fruits. It acts as an inhibitor of ethylene action, resulting in a delay of the maturation process (Li et al., 2016). Similarly, 1-MCP is also employed to increase the shelf life of flowers after harvesting; the treatment with 1-MCP, for example, delayed the senescence of roses in 19 days (De Pietro et al., 2010).

There are no research results, however, showing the effect of 1-MCP on the attenuation of drought on soybean. In cotton (Gossypium hirsutum L.) subjected to drought, the increase of ethylene levels caused early senescence of leaves, which was delayed in plants treated with 1-MCP. As a result, plants increased water use efficiency and chlorophyll concentration, suggesting an attenuation of drought stress (Chen et al., 2015). It should be highlighted that each plant species may have a different response to 1-MCP, requiring an adjustment for each crop condition (Watkins, 2006).

Exposure of soybean to $1-\mathrm{MCP}$ at the flowering stage might attenuate the effects of water restriction on traits related to BNF, as well as the negative effects on plant development and yield components.

The objective of this work was to assess the effects of 1-methylcyclopropene (1-MCP) on traits related to biological nitrogen fixation on 'BRS 268' soybean (Glycine max) subjected to water restriction.

\section{Materials and Methods}

The experiment was carried out under greenhouse conditions at the department of agronomy of Universidade Estadual de Londrina, in the municipality of Londrina, in the state of Paraná, Brazil.

'BRS 268' soybean plants of determinate growth were grown in 5 -L ceramic pots containing $5 \mathrm{~kg}$ of substrate (topsoil:compost, 3:1, v/v). The results of chemical analysis (Silva, 2009) showed: $5.8 \mathrm{pH}$ $\left(\mathrm{CaCl}_{2}\right) ; 4.6 \mathrm{cmol}_{\mathrm{c}} \mathrm{dm}^{-3} \mathrm{Ca}^{2+} ; 1.6 \mathrm{cmol}_{\mathrm{c}} \mathrm{dm}^{-3} \mathrm{Mg}^{2+}$; $0.0 \mathrm{cmol}_{\mathrm{c}} \mathrm{dm}^{-3} \mathrm{Al}^{3+} ; 2.5 \mathrm{cmol}_{\mathrm{c}} \mathrm{dm}^{-3} \mathrm{H}^{+}+\mathrm{Al}^{3+} ; 1.1 \mathrm{cmol}_{\mathrm{c}}$ $\mathrm{dm}^{-3} \mathrm{~K}^{+} ; 13.4 \mathrm{~g} \mathrm{~kg}^{-1} \mathrm{C} ; 23.0 \mathrm{~g} \mathrm{~kg}^{-1}$ organic matter; $57.8 \mathrm{mg} \mathrm{dm}^{-3} \mathrm{P}$; cation exchange capacity at $\mathrm{pH} 7.0$ of $9.8 \mathrm{cmol}_{\mathrm{c}} \mathrm{dm}^{-3}$; and base saturation of $75 \%$.

Soybean seeds were inoculated with peat-based inoculant containing $1 \times 10^{9}$ cells $\mathrm{g}^{-1}$ of $\mathrm{N}$-fixing bacteria, Bradyrhizobium spp., of the Semia 587 and
Semia 5080 strains (Rizo-Liq, Rizobacter do Brasil, Cambé, PR, Brazil). Five seeds were sown per pot and thinned to two plantlets at the $\mathrm{V}_{2}$ stage (Fehr \& Caviness, 1977). The treatments consisted of two water conditions: well-watered or dry, in combination with exposure or not to $1-\mathrm{MCP}$ at the $\mathrm{R}_{2}$ stage, forming a $2 \times 2$ factorial arrangement, in an completely randomized design, with eight replicates.

Ninety-six pots containing soybean plants were mounted to be assessed at 37 and 47 days after sowing (DAS), as well as at physiological maturity. All plants were well watered (water replacement to reach $80 \%$ field capacity) up to 32 DAS, corresponding to the $\mathrm{R}_{2}$ reproductive stage. From 32 DAS on, drought-simulation watering was applied to reach only $40 \%$ soil field capacity in the dry treatments, whereas well-watered plants continued to receive water to reach $80 \%$ field capacity. The water conditions were kept by weighing each pot daily and replacing the amount of water lost in each water condition. At 34 DAS (two days under water restriction), plants of 48 plots were exposed to 1-MCP, and at 37 DAS (four days under water restriction), 32 plots were analyzed. Water restriction was carried out up to $47 \mathrm{DAS}$, at the $\mathrm{R}_{3}$ stage, i.e., 15 days under drought, when another assessment was made in 32 plots. From 48 DAS on, 32 remaining plots were kept under well-watered conditions up to physiological maturity $\left(\mathrm{R}_{8}\right)$, when they were evaluated for the following yield components: number of pods and seeds per plants, and mass of seeds.

The trial was performed from February to June 2010, using 'BRS 268' soybean, tolerant to photoperiod. Average air temperatures in the period were: maximum of $26.7^{\circ} \mathrm{C}$, average of $21.4^{\circ} \mathrm{C}$, and minimum of $16.1^{\circ} \mathrm{C}$. The average relative humidity was $74 \%$.

The exposure to 1-MCP occurred in a $1.50-\mathrm{m}^{3}$ hermetically sealed plastic chamber, in which $6.4 \mathrm{~g}$ of the formulated product AFxRD-014 (SmartFresh, Agrofresh, Inc., Collegeville, PA, USA) were dissolved in $75 \mathrm{~mL}$ deionized water and kept in an open beaker. Considering the amount of 1-MCP and its vapor pressure, the air-solution surface, and the chamber volume, the estimated concentration in the atmosphere was $1,000 \mathrm{ppb}$. To assure a homogeneous distribution, fans were placed within the chamber. Control plants not exposed to 1-MCP were kept in an identical chamber in another greenhouse to avoid contamination. After 15 hours, plants from both treatments were maintained 
in the same greenhouse. Green tomatoes (Solanum lycopersicum L.) were kept in the hermetically sealed chambers along with the evaluated plants to check the effect of 1-MCP application, which caused late ripening of the tomato fruits.

At the $R_{2}$ and $R_{3}$ stages, shoots were cut just above the cotyledonal node, early in the morning. A $200-\mu \mathrm{L}$ pipette tip was fit onto the stump to collect the flowing sap coming from the roots. To make sap exudation easier, all pots received $1.2 \mathrm{~L}$ of water the night before. Sap samples were collected with a micropipette and stored in microtubes at $-15^{\circ} \mathrm{C}$ until analysis for ureides (Vogels $\&$ Van der Drift, 1970; Hungria, 1994). Briefly, $5 \mu \mathrm{L}$ of sap, in duplicate, were subjected to a sequence of alkaline and acid hydrolysis and to colorimetric quantification at $535 \mathrm{~nm}$ after reaction with phenylhydrazine and potassium ferricyanide. Data were expressed as nmol of ureides per millimeter of sap.

Plants collected at the $R_{2}$ and $R_{3}$ stages were also assessed for number and mass of root nodules. Leaf area was determined in a leaf area meter, model LI-3100 (LI-COR, Lincoln, NE, USA) and used to calculate the leaf area index (LAI) (Adami et al., 2008). Shoot and root dry weights were obtained after forced-air oven-drying, at $65^{\circ} \mathrm{C}$, until constant weight. The concentration of $\mathrm{N}$ in shoots was based on the Kjeldahl method in sulfuric-acid digested extracts (Tedesco et al., 1995). Plants remaining up to the $\mathrm{R}_{8}$ stage were evaluated for number of pods and seeds, and mass of seeds per plant.

The dataset was subjected to a two-way analysis of variance for each evaluation date, following Tukey's test, at $5 \%$ probability.

\section{Results and Discussion}

The exposure to $1-\mathrm{MCP}$ at $\mathrm{R}_{2}$, that is, four days under water restriction and three days after exposure to 1-MCP, resulted in higher nodule dry weight and higher ureide contents in the sap of plants. Considering the effect of water condition, water restriction increased the concentration of ureides in the sap of plants exposed to 1-MCP, but decreased it in plants not exposed to the compound; however, under well-watered conditions, the exposure to 1-MCP decreased the concentration of ureides. Under dry conditions, the concentration of $\mathrm{N}$ in leaves decreased, regardless of the exposure to $1-\mathrm{MCP}$ (Table 1), whereas the other variables related to plant growth (shoot and root dry weights) and the LAI were not affected. Although no effect was observed on plant growth-related parameters, water restriction for only four days showed negative effects on BNF-related parameters. According to the literature, an increase in ureides can be attributed to an impairment of assimilation and transportation of $\mathrm{N}$ compounds caused by drought, which may lead to a feedback inhibition of the BNF process (King \&

Table 1. Assessments of 'BRS 268' soybean (Glycine max) plants at the $\mathrm{R}_{2}$ stage, on the fourth day under water restriction and three days after exposure to 1-methylcyclopropene (1-MCP), and their respective controls ${ }^{(1)}$.

\begin{tabular}{|c|c|c|c|}
\hline $\begin{array}{l}\text { Variables/ } \\
\text { treatments }\end{array}$ & $\begin{array}{l}\text { Exposed to } \\
1-\mathrm{MCP}\end{array}$ & $\begin{array}{l}\text { Not exposed to } \\
1-\mathrm{MCP}\end{array}$ & Average \\
\hline & \multicolumn{3}{|c|}{ Number of nodules per plant } \\
\hline Dry & $45.68 \mathrm{Aa}$ & $35.62 \mathrm{Aa}$ & $40.65 \mathrm{~A}$ \\
\hline Well watered & $42.43 \mathrm{Aa}$ & $38.06 \mathrm{Aa}$ & $40.25 \mathrm{~A}$ \\
\hline Average & $44.06 \mathrm{a}$ & $36.84 \mathrm{a}$ & - \\
\hline \multirow[t]{2}{*}{ CV and p-value ${ }^{(2)}$} & \multicolumn{3}{|c|}{$26.3 \% ; \mathrm{W}=0.9148 ; \mathrm{M}=0.0652 ; \mathrm{WxM}=0.4560$} \\
\hline & \multicolumn{3}{|c|}{ Nodule dry weight $(\mathrm{mg})$} \\
\hline Dry & $71.62 \mathrm{Aa}$ & $50.25 \mathrm{Ab}$ & $60.93 \mathrm{~A}$ \\
\hline Well watered & $58.69 \mathrm{Aa}$ & $67.02 \mathrm{Aa}$ & $62.87 \mathrm{~A}$ \\
\hline Average & $65.15 \mathrm{a}$ & $58.65 \mathrm{a}$ & - \\
\hline \multirow[t]{2}{*}{ CV and $p$-value } & \multicolumn{3}{|c|}{$29.1 \% ; \mathrm{W}=0.7630 ; \mathrm{M}=0.3162 ; \mathrm{WxM}=0.0270$} \\
\hline & \multicolumn{3}{|c|}{ Root dry weight $(\mathrm{g})$} \\
\hline Dry & $0.92 \mathrm{Aa}$ & $0.77 \mathrm{Aa}$ & $0.85 \mathrm{~A}$ \\
\hline Well watered & $0.84 \mathrm{Aa}$ & $0.70 \mathrm{Aa}$ & $0.77 \mathrm{~A}$ \\
\hline Average & $0.88 \mathrm{a}$ & $0.73 \mathrm{a}$ & - \\
\hline \multirow[t]{2}{*}{$\mathrm{CV}$ and $\mathrm{p}$-value } & \multicolumn{3}{|c|}{$32.9 \% ; \mathrm{W}=0.4005 ; \mathrm{M}=0.1343 ; \mathrm{WxM}=0.9843$} \\
\hline & \multicolumn{3}{|c|}{ Shoot dry weight $(\mathrm{g})$} \\
\hline Dry & $5.38 \mathrm{Aa}$ & $4.28 \mathrm{Aa}$ & $4.83 \mathrm{~A}$ \\
\hline Well watered & $4.80 \mathrm{Aa}$ & $4.45 \mathrm{Aa}$ & $4.63 \mathrm{~A}$ \\
\hline Average & $5.09 \mathrm{a}$ & $4.37 \mathrm{a}$ & - \\
\hline \multirow[t]{2}{*}{$\mathrm{CV}$ and $\mathrm{p}$-value } & \multicolumn{3}{|c|}{$25.4 \% ; \mathrm{W}=0.6408 ; \mathrm{M}=0.0996 ; \mathrm{WxM}=0.3909$} \\
\hline & \multicolumn{3}{|c|}{ Total ureides in sap $\left(\mathrm{nmol} \mathrm{mL}^{-1}\right)$} \\
\hline Dry & $7.42 \mathrm{Aa}$ & $4.50 \mathrm{Bb}$ & $5.96 \mathrm{~A}$ \\
\hline Well watered & $3.50 \mathrm{Bb}$ & $6.15 \mathrm{Aa}$ & $4.82 \mathrm{~B}$ \\
\hline Average & $5.46 \mathrm{a}$ & $5.33 \mathrm{a}$ & - \\
\hline \multirow[t]{2}{*}{ CV and p-value } & \multicolumn{3}{|c|}{$24.9 \% ; \mathrm{W}=0.0237 ; \mathrm{M}=0.790 ; \mathrm{WxM}<0.0001$} \\
\hline & \multicolumn{3}{|c|}{ Leaf area index $\left(\mathrm{cm}^{2} \mathrm{~cm}^{-2}\right)$} \\
\hline Dry & 3.79Aa & $3.09 \mathrm{Aa}$ & $3.44 \mathrm{~A}$ \\
\hline Well watered & 3.43Aa & $3.20 \mathrm{Aa}$ & $3.31 \mathrm{~A}$ \\
\hline Average & $3.61 \mathrm{a}$ & $3.15 \mathrm{a}$ & - \\
\hline \multirow[t]{2}{*}{$\mathrm{CV}$ and $\mathrm{p}$-value } & \multicolumn{3}{|c|}{$22.9 \% ; \mathrm{W}=0.6422 ; \mathrm{M}=0.1009 ; \mathrm{WxM}=0.3961$} \\
\hline & \multicolumn{3}{|c|}{$\mathrm{N}$ concentrations in leaves $\left(\mathrm{g} \mathrm{kg}^{-1}\right)$} \\
\hline Dry & $48.15 \mathrm{Ba}$ & 47.76Aa & $47.95 \mathrm{~B}$ \\
\hline Well watered & $53.59 \mathrm{Aa}$ & $50.46 \mathrm{Aa}$ & $52.02 \mathrm{~A}$ \\
\hline Average & $50.87 \mathrm{a}$ & $49.11 \mathrm{a}$ & - \\
\hline $\mathrm{CV}$ and $\mathrm{p}$-value & \multicolumn{3}{|c|}{$7.7 \% ; \mathrm{W}=0.0058 ; \mathrm{M}=0.2076 ; \mathrm{WxM}=0.3228$} \\
\hline
\end{tabular}


Purcell, 2005). Sinclair et al. (2007) found differences between genotypes exposed to drought regarding $\mathrm{N}$ concentration in leaves. However, there have been no reports on the effect of 1-MCP on $\mathrm{N}$ compounds or even on $\mathrm{N}$ concentration in leaves of soybean exposed to drought. The present study, therefore, is apparently the first known work on 1-MCP effect on soybean exposed to drought.

Table 2. Assessments of 'BRS 268' soybean (Glycine max) plants at the $\mathrm{R}_{3}$ stage, on the fifteenth day under water restriction and 12 days after exposure to 1-methylcyclopropene (1-MCP), and their respective controls ${ }^{(1)}$.

\begin{tabular}{|c|c|c|c|}
\hline $\begin{array}{l}\text { Variables/ } \\
\text { treatments }\end{array}$ & $\begin{array}{l}\text { Exposed to } \\
1-\mathrm{MCP}\end{array}$ & $\begin{array}{l}\text { Not exposed to } \\
1-\mathrm{MCP}\end{array}$ & Average \\
\hline & \multicolumn{3}{|c|}{ Number of nodules per plant } \\
\hline Dry & $50.00 \mathrm{Ba}$ & $31.50 \mathrm{Bb}$ & $40.75 \mathrm{~B}$ \\
\hline Well watered & $75.12 \mathrm{Aa}$ & $59.62 \mathrm{Ab}$ & $67.37 \mathrm{~A}$ \\
\hline Average & $62.56 \mathrm{a}$ & $45.56 \mathrm{~b}$ & - \\
\hline \multirow[t]{2}{*}{ CV and p-value ${ }^{(2)}$} & \multicolumn{3}{|c|}{$24.2 \% ; \mathrm{W}<0.0001 ; \mathrm{M}=0.001 ; \mathrm{WxM}=0.7479$} \\
\hline & \multicolumn{3}{|c|}{ Nodule dry weight $(\mathrm{mg})$} \\
\hline Dry & $127.75 \mathrm{Ba}$ & $102.25 \mathrm{Ba}$ & 115.00B \\
\hline Well watered & $246.87 \mathrm{Aa}$ & $155.37 \mathrm{Ab}$ & $201.12 \mathrm{~A}$ \\
\hline Average & $187.31 \mathrm{a}$ & $128.81 \mathrm{~b}$ & - \\
\hline \multirow[t]{2}{*}{ CV and p-value } & \multicolumn{3}{|c|}{$\mathrm{W}=<0.0001 ; \mathrm{M}=0.0012 ; \mathrm{WxM}=0.051$} \\
\hline & \multicolumn{3}{|c|}{ Root dry weight $(\mathrm{g})$} \\
\hline Dry & $1.20 \mathrm{Aa}$ & $1.29 \mathrm{Aa}$ & $1.25 \mathrm{~A}$ \\
\hline Well watered & $1.56 \mathrm{Aa}$ & $1.37 \mathrm{Aa}$ & $1.46 \mathrm{~A}$ \\
\hline Average & $1.38 \mathrm{a}$ & $1.33 \mathrm{a}$ & - \\
\hline \multirow[t]{2}{*}{$\mathrm{CV}$ and $\mathrm{p}$-value } & \multicolumn{3}{|c|}{$29.4 \% ; \mathrm{W}=0.1371 ; \mathrm{M}=0.7326 ; \mathrm{WxM}=0.3302$} \\
\hline & \multicolumn{3}{|c|}{ Shoot dry weight $(\mathrm{g})$} \\
\hline Dry & $5.97 \mathrm{Ba}$ & $5.37 \mathrm{Ba}$ & $5.67 \mathrm{~B}$ \\
\hline Well watered & 7.38Aa & 7.39Aa & $7.39 \mathrm{~A}$ \\
\hline Average & $6.67 \mathrm{a}$ & $6.38 \mathrm{a}$ & - \\
\hline \multirow[t]{2}{*}{$\mathrm{CV}$ and $\mathrm{p}$-value } & \multicolumn{3}{|c|}{$20.3 \% ; \mathrm{W}=0.0010 ; \mathrm{M}=0.537 ; \mathrm{WxM}=0.5131$} \\
\hline & \multicolumn{3}{|c|}{ Total ureides in sap $\left(\mathrm{nmol} \mathrm{mL} \mathrm{mL}^{-1}\right)$} \\
\hline Dry & $8.90 \mathrm{Aa}$ & $9.40 \mathrm{Aa}$ & $9.15 \mathrm{~A}$ \\
\hline Well watered & $10.42 \mathrm{Aa}$ & $5.42 \mathrm{Bb}$ & $7.92 \mathrm{~A}$ \\
\hline Average & $9.66 \mathrm{a}$ & $7.41 \mathrm{~b}$ & - \\
\hline \multirow{2}{*}{ CV and p-value } & \multicolumn{3}{|c|}{$32.1 \% ; \mathrm{W}=0.2147 ; \mathrm{M}=0.028 ; \mathrm{WxM}=0.0085$} \\
\hline & \multicolumn{3}{|c|}{ Leaf area index $\left(\mathrm{cm}^{2} \mathrm{~cm}^{-2}\right)$} \\
\hline Dry & $4.18 \mathrm{Ba}$ & $3.79 \mathrm{Ba}$ & $3.99 \mathrm{~B}$ \\
\hline Well watered & 5.09Aa & 5.10Aa & $5.09 \mathrm{~A}$ \\
\hline Average & $4.63 \mathrm{a}$ & $4.44 \mathrm{a}$ & - \\
\hline \multirow[t]{2}{*}{$\mathrm{CV}$ and $\mathrm{p}$-value } & \multicolumn{3}{|c|}{$18.7 \% ; \mathrm{W}=0.001 ; \mathrm{M}=0.5347 ; \mathrm{WxM}=0.5109$} \\
\hline & \multicolumn{3}{|c|}{$\mathrm{N}$ concentrations in leaves $\left(\mathrm{g} \mathrm{kg}^{-1}\right)$} \\
\hline Dry & $38.97 \mathrm{Aa}$ & $40.60 \mathrm{Aa}$ & $39.78 \mathrm{~A}$ \\
\hline Well watered & $36.05 \mathrm{Aa}$ & $34.42 \mathrm{Ba}$ & $35.24 \mathrm{~B}$ \\
\hline Average & $37.51 \mathrm{a}$ & $37.51 \mathrm{a}$ & - \\
\hline $\mathrm{CV}$ and $\mathrm{p}$-value & \multicolumn{3}{|c|}{$11.1 \% ; \mathrm{W}=0.0045 ; \mathrm{M}=0.9975 ; \mathrm{WxM}=0.2775$} \\
\hline
\end{tabular}

The assessments at the $\mathrm{R}_{3}$ stage showed a more evident effect of water restriction in reducing nodulation, i.e., both number and mass of nodules, than at $\mathrm{R}_{2}$ (Table 2). In that stage, the exposure to 1-MCP stimulated nodulation, regardless of the water condition. With the exposure to $1-\mathrm{MCP}$, the concentration of ureides in the sap increased under well-watered conditions, but remained the same under dry ones; however, when plants were not exposed to $1-\mathrm{MCP}$, dry conditions resulted in an increase of ureides in the sap. The concentration of $\mathrm{N}$ in leaves did not change with the exposure to 1-MCP, but increased with drought in plants not exposed to 1-MCP.

Root dry weight was not affected by treatments, whereas shoot dry weight and the LAI decreased under water restriction (Table 2). This decrease in shoots under dry conditions can be responsible for higher $\mathrm{N}$ concentrations in plants, considering the concentration effect on smaller plants. An increase in $\mathrm{N}$ concentration in soybean with restricted growth due to drought has also been reported in another study (Streeter, 2003).

Water restriction reduced the number of pods by $14.5 \%$ and the mass of seeds by $12.2 \%$ in plants not exposed to 1-MCP (Table 3). It should be noted that shoot dry weight is highly related to the LAI, which

Table 3. Assessments relative to yield components of 'BRS 268 ' soybean (Glycine max) plants at the $\mathrm{R}_{8}$ stage, after exposure to water restriction and/or 1-methylcyclopropene (1-MCP) at the $\mathrm{R}_{2}$ stage, and their respective controls ${ }^{(1)}$.

\begin{tabular}{|c|c|c|c|}
\hline $\begin{array}{l}\text { Variables/ } \\
\text { treatments }\end{array}$ & $\begin{array}{l}\text { Exposed to } \\
1-\mathrm{MCP}\end{array}$ & $\begin{array}{l}\text { Not exposed } \\
\text { to } 1-\mathrm{MCP}\end{array}$ & Average \\
\hline & \multicolumn{3}{|c|}{ Number of pods per plant } \\
\hline Dry & $19.06 \mathrm{Aa}$ & $18.31 \mathrm{Ba}$ & $18.68 \mathrm{~B}$ \\
\hline Well watered & $21.75 \mathrm{Aa}$ & $21.93 \mathrm{Aa}$ & $21.84 \mathrm{~A}$ \\
\hline Average & $20.40 \mathrm{a}$ & $20.12 \mathrm{a}$ & - \\
\hline \multirow[t]{2}{*}{$\mathrm{CV}(\%)$ and $\mathrm{p}$-value } & \multicolumn{3}{|c|}{$13.9 \% ; \mathrm{W}=0.003 ; \mathrm{M}=0.7781 ; \mathrm{WxM}=0.6391$} \\
\hline & \multicolumn{3}{|c|}{ Number of seeds per plant } \\
\hline Dry & $40.43 \mathrm{Aa}$ & $39.43 \mathrm{Aa}$ & 39.93B \\
\hline Well watered & 46.12Aa & $44.81 \mathrm{Aa}$ & $45.46 \mathrm{~A}$ \\
\hline Average & $43.28 \mathrm{a}$ & $42.15 \mathrm{a}$ & - \\
\hline \multirow[t]{2}{*}{$\mathrm{CV}(\%)$ and $\mathrm{p}$-value } & \multicolumn{3}{|c|}{$13.4 \% ; \mathrm{W}=0.0107 ; \mathrm{M}=0.5722 ; \mathrm{WxM}=0.939$} \\
\hline & \multicolumn{3}{|c|}{ Mass of seeds per plant $(\mathrm{g})$} \\
\hline Dry & $8.98 \mathrm{Aa}$ & $8.54 \mathrm{Ba}$ & $8.76 \mathrm{~B}$ \\
\hline Well watered & $10.06 \mathrm{Aa}$ & $9.90 \mathrm{Aa}$ & $9.98 \mathrm{~A}$ \\
\hline Average & $9.52 \mathrm{a}$ & $9.22 \mathrm{a}$ & - \\
\hline
\end{tabular}

${ }^{(1)}$ Means followed by equal letters, uppercase in the columns and lowercase in the lines, do not differ by Tukey's test, at 5\% probability. CV (\%), coefficient of variation and $\mathrm{p}$-value for water condition $(\mathrm{W}=), 1-\mathrm{MCP}(\mathrm{M}=)$, and $\mathrm{W} \times \mathrm{M}=$. 
may correlate with crop yield (Sartori et al., 2015). The assessment in $\mathrm{R}_{3}$ showed a reduction of the LAI under water restriction. Therefore, a reduction in yield caused by water restriction was also observed at the $\mathrm{R}_{8}$ stage (Table 3). Soybean plants subjected to water stress at early reproductive stages had $13.7 \%$ reduction in yield, but the exposure to 1-MCP at $\mathrm{R}_{2}$ attenuated losses. Even though the exposure to 1-MCP attenuated the effect of water restriction on nodulation, there was no significant effect on yield in this trial.

The effects of drought on traits related to BNF have been widely studied (King \& Purcell, 2005; Hungria et al., 2006; Sinclair et al., 2007; Cerezini et al., 2014). However, despite some works on cotton, flowers, and fruits (Serek et al., 2006; De Pietro et al., 2010; Chen et al., 2015; Li et al., 2016), there is no knowledge of researches on the effect of 1-MCP on soybean, aiming to the attenuate negative effects of ethylene induced by drought stress on plant senescence, including nodules. This strategy could help plants to cope with periods under water restriction and reduce the negative effects on BNF. However, more studies are needed to validate the technical and economic viability of 1-MCP application on commercial soybean crops exposed to drought.

\section{Conclusion}

The exposure to 1-methylcyclopropene at the beginning of water restriction attenuates the effects of drought on soybean (Glycine max) nodulation.

\section{Acknowledgements}

To Coordenação de Aperfeiçoamento de Pessoal de Nível Superior (Capes) and to Conselho Nacional de Desenvolvimento Científico e Tecnológico (CNPq), for funding this research.

\section{References}

ADAMI, M.; HASTENREITER, F.A.; FLUMIGNAN, D.L.; FARIA, R.T. de. Estimativa de área de folíolos de soja usando imagens digitais e dimensões foliares. Bragantia, v.67, p.1053-1058, 2008. DOI: $10.1590 / \mathrm{S} 0006-87052008000400030$

CEREZINI, P.; PÍPOLO, A.E.; HUNGRIA, M.; NOGUEIRA, M. A. Gas exchanges and biological nitrogen fixation in soybean under water restriction. American Journal of Plant Sciences, v.5, p.4011-4017, 2014. DOI: 10.4236/ajps.2014.526419.

CHEN, Y.; COTHREN, J.T.; CHEN, D.; IBRAHIM, A.M.H.; LOMBARDINI, L. Ethylene-inhibiting compound 1-MCP delays leaf senescence in cotton plants under abiotic stress conditions. Journal of Integrative Agriculture, v.14, p.1321-1331, 2015. DOI: 10.1016/S2095-3119(14)60999-0.

DE PIETRO, J.; MATTIUZ, B.-H.; MATTIUZ, C.F.M. Influência do 1-MCP na conservação pós-colheita de rosas cv. Vega. Ciência e Agrotecnologia, v.34, p.1176-1183, 2010. DOI: 10.1590/ S1413-70542010000500014.

FEHR, W.R.; CAVINESS, C.E. Stages of soybean development. Ames: Iowa State University of Science and Technology, 1977. 12p. (Special report, 80).

HUNGRIA, M. Metabolismo do carbono e do nitrogênio nos nódulos. In: HUNGRIA, M.; ARAÚJO, R.S. (Ed.). Manual de métodos empregados em estudos de microbiologia agrícola. Brasília: EMBRAPA-SPI, 1994. p.249-283. (EMBRAPA-CNPAF. Documentos, 46).

HUNGRIA, M.; FRANCHINI, J.C.; CAMPO, R.J.; CRISPINO, C.C.; MORAES, J.Z.; SIBALDELLI, R.N.R.; MENDES, I.C.; ARIHARA, J. Nitrogen nutrition of soybean in Brazil: contributions of biological N2 fixation and $\mathrm{N}$ fertilizer to grain yield. Canadian Journal of Plant Sciences, v.86, p.927-939, 2006. DOI: 10.4141/ P05-098.

KING, C.A.; PURCELL, L.C. Inhibition of $\mathrm{N}_{2}$ fixation in soybean is associated with elevated ureides and amino acids. Plant Physiology, v.137, p.1389-1396, 2005. DOI: 10.1104/pp.104.056317.

LI, L.; LICHTER, A.; CHALUPOWICZ, D.; GAMRASNI, D.; GOLDBERG, T.; NERYA, O.; BEN-ARIE, R.; PORAT, R. Effects of the ethylene-action inhibitor 1-methylcyclopropene on postharvest quality of non-climacteric fruit crops. Postharvest Biology and Technology, v.111, p.322-329, 2016. DOI: 10.1016/j. postharvbio.2015.09.031.

NASCIMENTO, S.P. do; BASTOS, E.A.; ARAÚJO, E.C.E.; FREIRE FILHO, F.R.; SILVA, E.M. da. Tolerância ao déficit hídrico em genótipos de feijão-caupi. Revista Brasileira de Engenharia Agrícola e Ambiental, v.15, p.853-860, 2011. DOI: 10.1590/S1415-43662011000800013

SARTORI, G.M.S.; MARCHESAN, E.; DE DAVID, R.; CARLESSO, R.; PETRY, M.T.; DONATO, G.; CARGNELUTTI FILHO, A.; SILVA, M.F. da. Rendimento de grãos de soja em função de sistemas de plantio e irrigação por superfície em Planossolos. Pesquisa Agropecuária Brasileira, v.50, p.1139-1149, 2015. DOI: 10.1590/S0100-204X2015001200003.

SEREK, M.; WOLTERING, E.J.; SISLER, E.C.; FRELLO, S.; SRISKANDARAJAH, S. Controlling ethylene responses in flowers at the receptor level. Biotechnology Advances, v.24, p.368-381, 2006. DOI: 10.1016/j.biotechadv.2006.01.007.

SILVA, F.C. da. (Ed.). Manual de análises químicas de solos, plantas e fertilizantes. 2.ed. Brasília: Embrapa Informação Tecnológica; Rio de Janeiro: Embrapa Solos, 2009. 627p.

SINCLAIR, T.R.; PURCELL, L.C.; KING, C.A.; SNELLER, C.H.; CHEN, P.; VADEZ, V. Drought tolerance and yield increase of soybean resulting from improved symbiotic $\mathrm{N}_{2}$ fixation. Field Crops Research, v.101, p.68-71, 2007. DOI: 10.1016/j. fcr.2006.09.010. 
STREETER, J.G. Effects of drought on nitrogen fixation in soybean root nodules. Plant, Cell and Environment, v.26, p.1199-1204, 2003. DOI: 10.1046/j.1365-3040.2003.01041.x.

TEDESCO, M.J.; GIANELLO, C.; BISSANI, C.A.; BOHNEN, H.; VOLKWEISS, S.J. Análises de solo, plantas e outros materiais. 2.ed. Porto Alegre: UFRGS, 1995. 174p. (Boletim Técnico, 5).
VOGELS, G.D.; VAN DER DRIFT, C. Differential analysis of glyoxylate derivatives. Analytical Biochemistry, v.33, p.143-157, 1970. DOI: 10.1016/0003-2697(70)90448-3.

WATKINS, C.B. The use of 1-methylcyclopropene (1-MCP) on fruits and vegetables. Biotechnology Advances, v.24, p.389-409, 2006. DOI: 10.1016/j.biotechadv.2006.01.005.

Received on November 28, 2015 and accepted May 5, 2016 